\title{
ELECTORAL VIOLENCE IN KENYA 2007-2008 The Role of Vernacular Radio
}

\author{
Philip Onguny \\ Philip Onguny is Assistant Professor of Conflict Studies \\ Saint Paul University, Ottawa
}

\begin{abstract}
This article examines how the shifts in vernacular radio narratives influenced intergroup relations during the 2007-08 electoral violence in Kenya. Using media as an analytical framework, together with original in-depth interview data collected over four months of fieldwork in 2010, the article explores how vernacular radio listeners in Kisumu, Eldoret, and Nyeri interpreted the 2007-08 electoral violence prior to, during, and after the event. It argues that the framing of electoral stakes and subsequent violence by vernacular radio stations is mainly between differentiated and concerted frames, depending on the stage at which the violence manifests itself. Differentiated frames reinforce divisive and/or rebellious attitudes, and are likely to increase intergroup competition and further violence along ethnic lines. Concerted framing underpins the perceived areas of common interest believed to transcend disparate group allegiances, and this establishes the possibility of intergroup dialogue and collaborative attitudes. These findings also highlight the central role of ethno-linguistic proximity and ethno-regional polity as potential drivers of vernacular radio frames, particularly in situations of electoral violence.
\end{abstract}

Keywords: Kenya, media, framing, vernacular radio, ethnic conflicts, peacebuilding

\section{INTRODUCTION}

Kenya has recently witnessed a significant shift in its media landscape, in particular with the rapid growth of vernacular radio. While this increase may be applauded as one of the many efforts the country has made to reinforce political accountability and democratic liberties (Cottrell \& Ghai 2007), accommodating ethnic differences and interests remains a daunting task for media organisations. 
There are at least forty-two different ethno-linguistic groups in Kenya. Most are confined within specific regions such as Nyanza (Luo majority), Central (Kikuyu majority) and Rift Valley province (Kalenjin majority), all of which have recently been broken down into 47 counties. Further, the competitive nature of electoral processes in Kenya and recent proliferation of vernacular radio have served to strengthen ethno-political categorisation at the expense of national self-determination (Somerville 2009; Jamal \& Deane 2008).

Although the current media landscape may be seen in a positive light, the relationship between the state and media outlets has always been uncertain (Odhiambo 2002). According to Throup and Hornsby (1998), the changes that accompanied political revolutions in the 1990s served to encourage the growth of independent media even though the government attempted to control media content through impromptu media bills and regulations. These practices saw a gradual institutionalisation of critical media. However, as Wanyande (1995) points out, the winds of change did not stop the government from disciplining the media whenever it failed to toe the line. Electoral cycles and their aftermath have increased government's attempt to control media narratives on the grounds of curbing hate messages. In addition to the brown envelopes taken by some journalists and editors to kill certain stories (Helander 2010; Lohner, Banjac \& Neverla 2016), these actions have raised questions with regard to the linkages between media content and political agendas. Further, some studies have shown that the state has found a new way of influencing media content through advertisements in exchange for friendly coverage (Ogola 2011).

Media ownership is another factor that questions the links between media content and political interests. For instance, Royal Media Services, owned by businessman Samuel K. Macharia, controls most of the radio market in Kenya with fourteen different radio stations, most of which broadcast in local languages.

It is therefore not uncommon for politics and corporate interests to infiltrate electoral processes through media ownership. A number of vernacular radio stations were accused of fanning the intergroup polarisation believed to have sparked the 2007-08 electoral violence (Jamal \& Deane 2008). Accommodating intergroup interests during electoral processes became a major challenge for ethnic media, particularly vernacular radio. This may explain why the Kenyan government has, in the past, imposed a temporary ban on all live media under the umbrella of public safety (Zuckerman 2009; Somerville 2009; Jamal \& Deane 2008). A similar pattern was witnessed in 2018, when the government threatened to shut down media houses that planned a live broadcast of the mock swearingin of opposition leader Raila Odinga as the people's president (Waweru 2018).

While it is yet to be determined whether vernacular radio narratives did play an active part in influencing the 2007-08 electoral violence, studies have 
shown that media discourse significantly influences the public's attitudinal changes, particularly in political processes (Gower \& An 2009; Entman 2010; Zuckerman 2009). Previous patterns of ethno-political violence in Africa also support this assumption. Rwanda's widely cited genocide was partly blamed on Radio Television Libre des Mille Collines (RTLM) and the magazine Kangura for allegedly spreading hate messages that led to intergroup killings (Thomson 2007). The 1993 political violence in Burundi is also believed to have been influenced by media narratives circulated through Témoin-Nyabusorongo (Kaburahe 2004). The Democratic Republic of Congo's La Voix du Patriote was perceived as one of the catalysts for the ongoing civil war (Frère 2009). The confirmation of charges by the International Criminal Court (ICC) against Joshua Sang, one of Kenya's talk-show vernacular radio journalists, added to this growing concern. Although he was acquitted of all charges, Mr. Sang had been accused of broadcasting 'anti-Kikuyu rhetoric when Kalenjins who were largely in support of the Orange Democratic Movement party lost the election in 2007' (Chepkoech 2015).

These cases suggest that media discourse consists of controlled narratives with calculated outcomes (Barker \& Knight, 2000). The question is why electoral competitions often shift from electoral discourse to embrace ethnicity. This question is largely ignored. Little attention has been paid to the conditions that encourage vernacular radio listeners to participate in electoral violence despite numerous studies that have shown the role of radio in incentivising violence. Extant literature on the topic often emphasises ethno-political stigmatisation and how it affects the politics of democratisation (Frere 2009; Tomaselli \& Muller, 2001). While it is true that such categorisation may lead to the escalation or deescalation of violence, the frame-building process and how it influences intergroup attitudinal shifts during electoral violence remains largely unexplored.

Against this backdrop, the central question this study addresses is: How do vernacular radio stations accommodate and/or negotiate intergroup relations during periods of electoral violence, and why do electoral processes shift from electoral discussion to embrace ethnicity? To achieve this, this article draws on framing as an analytical scaffold and the 2007-08 election violence as a case study. It also uses original in-depth interviews conducted over a four-month period in three disparate ethno-linguistic regions in Kenya. It argues that the shifts (in vernacular radio frames) from electoral discourse to negative ethnicity is partly due to the systematic categorisation of ethnic groups into competitive ethnopolitical pacts. Ethno-linguistic affinity thus serves as a vehicle by which group interests are produced, negotiated, and consumed or contested. This negotiation and/or accommodation of intergroup relations is understood here in terms of concerted and differentiated vernacular radio frames. 


\section{CONCEPTUAL CLARIFICATIONS AND THEORETICAL FRAMEWORK}

Ethnicity is used here to highlight a 'decision people make to depict themselves or others symbolically as the bearers of certain cultural identity' (Cohen 1994, p. 119). According to Jenkins (2004), ethnicity is closely intertwined with selfhood (how you see yourself) and personhood (how others see you). Osaghae (1999) argues that these form the larger structure explaining intergroup relations in both conflict and collaboration. The term conflict is understood in this article as 'a situation in which two or more actors, who interact with each other, pursue incompatible goals, are aware of this incompatibility, and claim to be justified in the pursuit of their particular course of action' (Wolff 2004, p. 8). In this regard, goal incompatibility may generate wide-ranging sentiments such as discontent, aggression and assimilation.

The term vernacular radio is used for radio stations that broadcast in languages spoken by specific ethno-linguistic groups living in a multi-ethnic society where the politics of cultural hybridism is seemingly weakened by inter-ethnic interests and/or claims of ethnic essentialism. Vernacular radio stations often broadcast in non-official languages, although some societies are gradually recognising local dialects as official languages. This is the case in South Africa, where there have been eleven official spoken languages since 1994 (Lekgoathi 2012). The main particularity of vernacular radios is that they are likely to appropriate, customise and slant news for the specific groups they serve (Neyazi 2010).

Finally, the concept of framing is used to underpin the structures that help interpret perceived reality. Thus, media framing highlights the processes and structures of interpretation proposed through news storylines to reinforce a particular meaning with regard to the public perception of an occurrence (Gower \& An 2009). In this way, framing is essentially a matter of negotiation and salience.

The framing process thus provides the theoretical basis for the article. Early definitions of framing are often associated with Goffman's (1974) work, highlighting the cognitive structures that assist individual interpretation of perceived reality and/or social phenomena. According to Goffman, daily life experience not only structures our perceptions of social order, it organises and ritualises the representation of self in what he called 'staged performances'. In essence, Goffman's argument is that framing is a twofold process which, on the one hand, portrays self as a construct hinged on selective representations of reality, and on the other, mirrors individual interactions with the immediate environment. Frames, in this regard, reflect both the conscious state of mind (because individuals somehow manipulate situational norms to present their self in a controlled manner) and the unconscious (since a normalised social order limits the individual capacity to freely represent the self). 
Since Goffman's conception of framing is a continuous process of making sense, it has been widely appropriated in academic literature with varying definitions, depending on the field of study. For instance, communication scholars such as Entman (1993, p. 52) consider framing as a process whereby people identify 'some aspects of a perceived reality and make them more salient in a communicating text, in such a way as to promote a particular problem definition, causal interpretation, moral evaluation, and/or treatment recommendation'. More recently, scholars such as Matthes (2012) and D'Angelo (2011) have argued for an integrative approach to framing, suggesting that news frames not only disseminate persuasive angles of news interpretation, they also provide reasons why such frames are of great importance.

Scholars such as D'Angelo (2011) see framing as a dual concept whereby researchers bring together various angles of news analyses so they fit into a given conceptual frame of analysis. Thus, to understand the complexity of framing as a process, it is necessary to examine the selective processes that accompany the production and dissemination of news content (Matthes 2012; Entman 2010). Other communication scholars have also associated framing with priming and agenda-setting to emphasise the selective processes that alter audience perception and world views (Weaver 2007; Shah et al. 2009). At the core of these views is the assumption that media professionals 'construct the symbolic representations of society that members of the public use to make sense of events and issues' (Bronstein 2005, p. 785). Factors such as technological progress, journalistic orientation, financial pressure and corporate interest, are some of the conditions believed to influence media frames (Entman 2010).

Framing is also prevalent in mediation and negotiation literature, where it underscores the cognitive bargaining processes in which disputants weigh their gains or losses. Schweitzer, DeChurch and Gibson (2005, p. 2124) remind us that 'competitively framed negotiators tend to perceive their dispute as one in which one party gains at the other's expense, [while] cooperatively framed negotiators tend to perceive their dispute as an opportunity to create an integrative agreement that benefits both parties'. Understood as such, framing is fundamentally a communicative and integrative process poised on rhetorical structures and their degrees of congruence. This is predicated on the assumption that media representations are, above all, controlled narratives geared towards influencing public opinion, depending on their representational aptitudes (Lecheler \& de Vreese 2012).

From these perspectives, framing broadly represents a schema of interpretation socially constructed through news story lines to influence audience perception of a phenomenon (Tewksbury \& Scheufele 2009; Avraham \& First 2010). The argument is that social identity, including ethnic identity, is constructed on 
the group or collective frame of reference. This self-categorisation process is fluid and shifts depending on circumstances as was evident, for example, in the intense media coverage of the War on Terror (Simons 2008; Altheide 2009). The cultures of proximity often create a sense of solidarity and/or symbolic community based on perceived threats, interests, and expected outcomes (Kolmer \& Semetko 2009).

This brief overview of the framing perspective points to the duality inherent in vernacular radio coverage of competitive events such as elections in Africa, which often become ethnic. On the one hand is the need to understand the intricate relationship between framing as a persuasive discourse involving the strategic intentions of disputants; and on the other, framing is a communicative process exemplifying interpretive orientations (Kaufman \& Smith 1999). As an interpretative tool, framing can serve as a mental map allowing individuals to make sense of situations based on their own world views and lived experiences. This underscores the hegemonic power associated with media frames in political processes (El-Nawawy \& Powers 2010). As Entman (2010, p. 389) reminds us, 'slanted framing results from the interaction of real-world developments, cultural norms, and journalistic decision rules with the sometimes proficient and other times maladroit efforts of competing elites to manage the news'. It is along these lines that framing was adopted in this study as an analytical framework.

\section{METHODOLOGY AND CHOICE OF RESEARCH SITES}

The study draws primarily on in-depth interviews during four months of fieldwork in Kenya conducted in 2010 in three ethno-linguistic locations: Kisumu, Nyeri and Eldoret, selected for the following reasons:

Kisumu was targeted because the Luo, Kenya's third major ethnic group, are the dominant ethnic group. It is also close to Bondo, home to Raila Odinga, the former Prime Minister of Kenya and presidential candidate in the contentious 2007-08 elections as well as in 2013 and, unsuccessfully, in 2017. More importantly, Kisumu was among the worst affected areas during the 2007-08 post-election violence. It has often been regarded as a base for the country's opposition politics since the acrimonious political split between Jomo Kenyatta, Kenya's first president, and the then-vice-president, Jaramogi Oginga Odinga (father of Raila Odinga), in 1966.

Eldoret was selected because it is home to the Kalenjin, Kenya's fourth largest ethnic group. Eldoret is close to Kabarnet, home to the former head of state, Daniel T. Arap Moi, whose regime lasted for more than two decades (19782002). Eldoret was also one of the hot spots during the 2007-08 electoral violence, where individuals were burned alive inside the Kenya Assemblies of God Church building in Kiambaa (Rice 2008). Furthermore, William Ruto, then Eldoret North's member of parliament and subsequently deputy president, had been indicted 
by the International Criminal Court (ICC) for alleged crimes against humanity committed during the 2007-08 conflicts. Uhuru Kenyatta was similarly accused but was acquitted when the charges were dropped, became president in 2013 and was re-elected in 2018.

The third area, Nyeri, was considered a suitable research site because it is located in the former Central Province, mainly inhabited by the Kikuyu, Kenya's largest ethnic group according to the 2009 census. Nyeri is also close to Othaya, home to former president Mwai Kibaki whose controversial re-election sparked the 2007-08 electoral violence. In addition, the first president of Kenya, Jomo Kenyatta, and the fourth president, Uhuru Kenyatta, hail from Gatundu, also in the former Central Province.

Overall, the choice of these research sites was motivated by the dominant ethnic languages spoken, historical contingencies, and the impact that the 200708 election violence had on ethno-linguistic populations in these locations, as reported by Human Rights Watch (2009). One of the limitations facing the study was that it relied on reported accounts of vernacular radio listeners in the target ethno-linguistic locations as a means to identify the dominant views that may have been advanced before, during, and after the 2007-08 electoral violence. This is because radio recordings were not accessible for analysis, as there were parallel ICC-led investigations taking place during the time of the fieldwork (June-September 2010). Several broadcasters were unwilling to provide access to their recordings.

Further, since the study targeted specific ethno-linguistic regions (and related vernacular radios), it did not generalise its findings. The results presented are therefore meant to offer the possibility of studying other regions to determine whether or not similar patterns of frames may emerge during electoral violence. The study also relied on a total of 45 respondents, 15 in-depth interviews per location across different demographics. Recruitment criteria included the completion of primary education and a comprehensive knowledge of English, to avoid translated materials that might not reflect respondents' opinions. Finally, target respondents needed to reflect the study's target groups: Luo, Kalenjin and Kikuyu. Frame clusters were then generated from these interviews to determine the dominant clusters of frames in the three locations of study.

\section{RESULTS}

The results indicate an erratic pattern regarding the accommodation and negotiation of intergroup relations in the period leading to the 2007-08 conflicts which were dependent on the stage at which the violence unfolded. Prior to active violence, intergroup relations were negotiated along past historical contingencies. During the active violence, the narratives of cross-victimisation and 
group survival appeared to be particularly salient. Following the period of active violence, the negotiation of intergroup relations took the form of civic ideals cutting across group allegiances.

\section{Pre-conflict Phase}

Considering the overall attitude towards the elections, the interviews suggest that the negotiation of intergroup relations centred on past historical contingencies. Most of these were linked to the colonial legacy that had led to the disintegration of local groups in an effort to create administrative boundaries, without paying attention to traditional bonds that held the groups together. In concrete terms the interviews revealed that land ownership, political representation, and group economic emancipation were key markers of intergroup relations, depending on how they were negotiated and disseminated to radio listeners.

For instance, the thorny issue of resettlement schemes following Kenya's independence from Britain in 1963 was emphasised by Kikuyu and Kalenjin radio stations to characterise intergroup relationships prior to the elections. At the core of these characterisations were the Majimbo (Swahili for devolutionism or regionalism) constitutional debates, salient in both Nyeri and Eldoret. While the interview with Kikuyu-language radio listeners emphasised the narratives of eviction as being the most dominant angle of news coverage, Kalenjin radio listeners pointed out that narratives of invasion (by the supposed Kikuyu 'foreign settlers') were accentuated. Luo-language radio listeners, on the other hand, indicated that intergroup relations were essentialised as a problem of political representation and the alleged betrayal by the Kibaki government following its election in 2002. This is how one of the respondents from Kisumu summarised these discussions:

... There was a sense of betrayal from the Kikuyu once Kibaki became the president in 2002. When Odinga campaigned so hard for him in 2002, Kikuyu and Luos were best friends. Once they [Kikuyu] got what they wanted, they decided to turn their backs from the very people who voted for them and disregarded the reforms that Odinga and other politicians campaigned for... . It was normal for the Luo voters to be reminded about what had happened in 2002 so that they are not fooled again.

(interview with a Luo radio listener, Kisumu, July 10, 2010).

Despite the differences in framing, Luo and Kalenjin radio listeners indicated that the narratives adopted by their respective radio stations demonised the Kibaki- 
led Party of National Unity (PNU). This strengthened the perception that the Kikuyu were the primary beneficiaries of the Kibaki government, and that it was necessary to fight for equity between groups. On the other hand, the interviews indicate that stations broadcasting in the Kikuyu language may have portrayed the Odinga-led Orange Democratic Movement (ODM) as an ethnically-minded party, and that its party leader could not be trusted with the country's leadership, presumably because of his dictator-like tendencies.

While the pre-conflict stage was characterised by dispersed frames with respect to electoral stakes, there were varying explanations of intergroup polarisation in the period leading to the 2007-08 election violence. Table 1 below indicates the dominant frames adopted by vernacular radio prior to the 2007-08 election violence.

Table 1: Dominant frames prior to active violence

\begin{tabular}{|l|c|c|c|}
\hline \multirow{2}{*}{ Framing category } & \multicolumn{3}{|c|}{$\begin{array}{c}\text { Dominant frames relating to intergroup polarisation } \\
\text { prior to the 2007-08 violence }\end{array}$} \\
\cline { 2 - 4 } & $\begin{array}{c}\text { Kisumu } \\
(\mathbf{n = 1 5 )}\end{array}$ & $\begin{array}{c}\text { Eldoret } \\
(\mathbf{n = 1 5 )}\end{array}$ & $\begin{array}{c}\text { Nyeri } \\
(\mathbf{n = 1 5})\end{array}$ \\
\hline Ethno-regional marginalisation & 13 & 9 & 6 \\
\hline Unfair land ownership & 10 & 15 & 5 \\
\hline Land ressettlement scores & 7 & 6 & 15 \\
\hline Dissent over a Luo presidency & 14 & 10 & 2 \\
\hline $\begin{array}{l}\text { Dissent over Kikuyu economic } \\
\text { successes }\end{array}$ & 3 & 5 & 13 \\
\hline
\end{tabular}

\section{Dominant frames during active violence}

Active violence was sparked by the announcement of presidential results giving outgoing president Kibaki a second term. During this period interviews showed that vernacular radio may have shifted its narratives from historically-situated grievances to a discourse of intergroup cross-victimisation and finger-pointing. Here, vernacular radio seemed to have strengthened the perception that certain groups were victims of hate, mistreatment, unfairness and political opportunism, which may have reinforced sentiments of attack, counter-attack, and self-defence strategies.

In concrete terms, active violence frames emanating from Kisumu and Eldoret negatively represented the Kikuyu, often linking them to the incumbent government believed to have stolen the elections. The heavy deployment of the police force in Kisumu and Eldoret was presented as the government's move to 
contain dissent from the Luo and Kalenjin groups, initially perceived as ODM's core supporters. In the process, vote-rigging, intolerance and government oppression seemed to be the main reasons provided as justification for election violence. One respondent in Eldoret had this to say about the cause of violence against PNU affiliates:

All the opinion polls gave Raila a strong lead over Kibaki, even during the actual tallying of the votes. A day before the official results, there was confusion all over, with contradictory messages coming from different journalists. At one point, we hear that Raila had been declared the winner, the next minute we hear that it is actually Kibaki who took it. This is what sparked anger and violence against the PNU party and their Kikuyu members. Everyone went to vote in peace, and they started playing around with people's will.... You don't expect us to keep quiet and let go our hard-earned victory. It is like stepping on a snake expecting it not to bite back.

(interview with a Kalenjin radio listener, Eldoret, August 7, 2010)

Kikuyu radio listeners, on the other hand, reported that most Kikuyu-language radio stations discredited such claims and emphasised the alleged planned attack on the Kikuyu communities by the Luo and Kalenjin groups. According to the interviews, self-defence and the need for ethnic survival may have been the outcome of these contested narratives, which may explain why discussions around Mungiki gangs also became prevalent (see Rasmussen 2010, pp. 301-319).

Although vote-rigging was also a central feature of Kikuyu language radio programmes, these claims were mainly framed in a manner that represented the Kikuyu as the primary targets of planned attacks, and that vote-rigging was used by the Luo and Kalenjin sponsors of violence to consolidate support for their planned attacks. The interviews pointed to the possibility of some politicians using vernacular radio to instil sentiments of separation rather than intergroup cohesion. As one respondent from Nyeri reported:

Some of these radios [vernacular] are mouthpieces for local politicians who used them to spread hate while advancing their personal interests .... Many Kikuyus were targeted and killed for political reasons, and some [radios] openly called for the eviction of our communities yet these people have lived there [Rift Valley] for decades. Where do they expect them to go? When you are attacked you have to defend yourself. I don't see the problem with the radios telling our people 
to watch out for the attacks. Whether Mungiki was involved in the attacks or not, the point is, these were planned attacks against the Kikuyus, and we had the right to protect.

(interview with a Kikuyu radio listener, Nyeri, September 6, 2010)

Vernacular radio frames during the period of active violence suggested that other groups were either untrustworthy, hateful, vengeful or intolerant. The discourse of power struggles has become the core frame used by most of the radio stations to characterise intergroup relations. Violence was thus justified in terms of selfdefence and group survival. Table 2 displays the main categories of frames that emerged when target radio listeners were asked to describe the reasons provided for the shift from electoral dispute to inter-ethnic violence.

Table 2: Dominant frames during the active violence stage

\begin{tabular}{|l|c|c|c|}
\hline \multirow{2}{*}{ Framing category } & \multicolumn{3}{|c|}{$\begin{array}{c}\text { Dominant frames relating to intergroup } \\
\text { violence in 2007/08 }\end{array}$} \\
\cline { 2 - 4 } & $\begin{array}{c}\text { Kisumu } \\
(\mathbf{n = 1 5 )}\end{array}$ & $\begin{array}{c}\text { Eldoret } \\
(\mathbf{n = 1 5 )}\end{array}$ & $\begin{array}{c}\text { Nyeri } \\
\text { (n=15) }\end{array}$ \\
\hline Vote-rigging & 15 & 13 & 10 \\
\hline Planned attacks & 3 & 2 & 15 \\
\hline Government mischief & 14 & 11 & 4 \\
\hline Land and territorial insecurity & 6 & 15 & 14 \\
\hline Power struggles and political opportunism & 15 & 15 & 15 \\
\hline
\end{tabular}

\section{Dominant Frames after Active Violence}

Official figures provided by the independent inquiry commission, commonly known as the Waki Commission, indicated that violence claimed the lives of 1100 people and displaced more than 700000 others. Subsequently, target radio listeners reported that vernacular radio changed its narratives. This time peace negotiations led by Kofi Annan and the urgency to reunite ethnic factions have been the message endorsed by several vernacular radio stations. Rather than focusing on historically-grounded grievances and cross-victimisation, radio programmes emphasised peace talks underway between Kibaki and Odinga, the two main rival political party leaders. Instead of emphasising disparate ethnic interests, these programmes strengthened the perception of collective or communal interests that cut across intergroup allegiances. Intergroup relations were now negotiated in terms of civic ideals rather than the perceived gains and/ or losses of individual groups. 
The interviews also revealed that various radio stations heightened the perception of a joint nation-building process, often reminding audiences of their collective pride in national achievements within the international arena such as tourism and world marathons. Such elements bring a sense of collective pride and unity. Post conflict, i.e. after the stage of active violence, power-sharing, nation-building, democratic governance and intergroup reconciliation became key angles of news analysis. These all reinforced the notion of collective ideals, while at the same time, consoling the victims of election violence. For instance, a respondent from Nyeri stated:

[...] The radios were very important because people were calling to console one another and offer their support to those who were displaced from their homes in various parts of the Rift Valley. Although many people had lost their lives at this point, people came to realise that violence was not the best way to resolve political differences. The innocent are always the ones who have to pay a higher.

(interview with a Kikuyu radio listener, Nyeri, September 10, 2010)

In concrete terms, vernacular radio stations shifted their narratives from a discourse indicating the association of individual groups with specific political parties, to one emphasising the power-sharing deal advocated by Kofi Annan and his mediation team. This reinforced the perception that key political leaders were willing to put aside their differences in order to end the violence and political stalemate. Instead of focusing on individual group solutions to the violence and perceived flawed electoral process, collective solutions were encouraged. These included the need for democratic reforms, with a constitutional amendment regarded as the main solution to longstanding political and historically-situated grievances between groups.

Further, these radio stations emphasised youth involvement in active politics, thus moving post-electoral analysis away from finger-pointing to policy-based issues. For instance, a respondent in Eldoret noted that, 'although it is true that local [vernacular] radios communicated separation in the past, we should also recognise their efforts in bringing the communities together and talking about issues that had caused the conflict such as youth unemployment' (interview with a Kalenjin radio listener, Eldoret, August 24, 2010). A similar reaction came from another Kisumu respondent who pointed out that 'the radios [vernacular] preached peace by inviting church leaders on their talk shows rather than politicians who had personal agendas' (interview with a Luo radio listener, Kisumu, July 21, 2010). Similarly, an interviewee from Nyeri observed that 'gospel songs dominated the 
airwaves instead of politically-driven songs that caused tension between different ethnic groups just before the elections' (interview with a Kikuyu radio listener, Nyeri, September 6, 2010).

According to the interviews, several radios refrained from using provocative songs as interlude or signature tunes, as had been the case prior to and during the period of active violence. Instead, religious and Swahili language national songs dominated the airwaves indicating the power of song in shifting attitudes in both violent situations or in search of peace. Table 3 shows the dominant frames used to accommodate intergroup relations after the active violence:

Table 3: Dominant frames after the active violence stage

\begin{tabular}{|l|c|c|c|}
\hline \multirow{2}{*}{ Framing category } & \multicolumn{3}{|c|}{ Dominant frames following the active violence stage } \\
\cline { 2 - 4 } & $\begin{array}{c}\text { Kisumu } \\
(\mathbf{n}=\mathbf{1 5})\end{array}$ & $\begin{array}{c}\text { Eldoret } \\
(\mathbf{n = 1 5 )}\end{array}$ & $\begin{array}{c}\text { Nyeri } \\
(\mathbf{n}=\mathbf{1 5})\end{array}$ \\
\hline Power sharing & 9 & 13 & 10 \\
\hline Youth engagement & 14 & 12 & 13 \\
\hline Intergroup reconciliation & 12 & 10 & 14 \\
\hline Nation building & 13 & 11 & 13 \\
\hline Democratic governance & 14 & 13 & 14 \\
\hline
\end{tabular}

Overall, the interviews revealed that the dominant frames following the active violence stage were fairly similar across different research sites. This points to two probabilities: first, it suggests that differences in framing are likely to change attitudes to the use of violence as a means to settle political differences. Second, the change in the framing process is also likely to shift the course or patterns of violence and intergroup relations over time and space. Frames emphasising collective ideals are more likely to strengthen collaborative attitudes, while those underscoring ethnic group loyalties reinforce divisive and rebellious attitudes. The next section discusses these shifts in detail.

\section{DISCUSSION}

The study examines how shifts in vernacular radio narratives influence intergroup relations in situations of electoral violence in Kenya, with particular emphasis on that of 2007-08. The study also explores how and why election-related violence often shifts from electoral discourse to embrace ethnicity. Overall, the findings suggest a slanted framing process at different stages when violence manifested itself, most of which hinged on historical contingencies, intergroup crossvictimisation and the notion of collective interest. 
Prior to the active violence stage, historical grievances served as key drivers of news content and, by extension, the incentive to instil a sense of displeasure with the way the then-outgoing government had handled these perceived grievances. This explains why land ownership debates, emphasised by the Kalenjin and Kikuyu radio stations, resonated well with vernacular radio listeners in Eldoret and Nyeri. As other studies have also shown, questions about land ownership and resettlement policies have been particularly acute in these regions (Lynch 2008; Klaus 2015). The perception that the Kikuyu group were the primary beneficiaries of unfair land occupancy and tenure systems transformed into attacks and counter-attacks between the perceived invaders and evictor. Luo radio stations, on the other hand, reinforced the perception that the Kikuyu group were particularly opposed to Raila Odinga's presidency and, by extension, the Luo group's perceived ascendance to political power. From the framing perspective, this shows that negatively framed messages, whether true or false, reinforce divisive attitudes amongst various groups. Similarly, these frames show how cultural proximity and/or particularities can be conveniently used to define intergroup boundaries in violent situations. These factors may explain the ethnic turn in violent electoral processes.

Regarding the stage of active violence, the findings indicate that every group appeared to be a victim of something, with violence being justified on the grounds that it ensures group survival and self-defence. In so doing, vernacular radio stations appeared to mobilise and incentivise specific group beliefs to achieve specific objectives. These include generating a sense of intergroup mistrust while demonising other groups as the reason for their perceived suffering or political neglect. Accordingly, the results indicate that Luo language radio programmes emphasised the notion that the Kikuyu group had transformed the state into a family business in which other groups had only subordinate roles in state machinery. This perception was backed by narratives of vote-rigging and government mischief, and claims that the outgoing government was using the police force to contain political dissent. On the other hand, Kikuyu language radio stations explained the violence in terms of planned attacks by ODM party sympathisers, and that the party leader Raila Odinga was unwilling to concede defeat. For their part, Kalenjin language radio stations identified unfair land ownership as the primary cause of bad blood between Kikuyu and Kalenjin. Active violence frames therefore served to maintain intergroup distrust, thereby strengthening rebellious attitudes between different groups.

Finally, the results of the study indicate that post-conflict frames emphasised collaborative efforts to contain the violence after the 2007-08 election in order to reinforce intergroup reconciliation. Vernacular radio stations seemed bound together by the belief that a civil war was in the making and also by the fear that 
several radio stations risked being shut down. They thus changed their narratives from divisive frames to a position supporting ongoing power-sharing negotiations, often highlighting the need to collaborate in joint political problem-solving. The realisation that the violence had claimed innocent lives may have also been at the heart of the shifting narratives. In essence, the change in the framing process encouraged collaborative attitudes between groups and underpinned the urgency for dialogue and political settlement between the two party affiliates.

The central overarching message, according to the findings, was the need for political reforms. These were seen as the first step towards a meaningful solution of problems of governance and the restoration of intergroup trust which had been significantly eroded by acts of violence. Figure 1 below represents potential changes in vernacular radio frames and related attitudinal shifts during the 200708 election violence:

\begin{tabular}{|c|c|c|}
\hline Pre-active violence & Active violence & Post-active violence \\
\hline $\begin{array}{l}\text { - Perceptual } \\
\text { differences based } \\
\text { on political, } \\
\text { economic, cultural, } \\
\text { territorial and media } \\
\text { representations } \\
\text { - Narratives of image } \\
\text { correction, whether self } \\
\text { or group } \\
\text { - Potential frame outcomes: } \\
\text { Intergroup distrust and } \\
\text { demonisation; divisive } \\
\text { attitudes; violence as a } \\
\text { potential solution }\end{array}$ & $\begin{array}{l}\text { - Conflicting } \\
\text { perceptions } \\
\text { of self/group } \\
\text { and cross- } \\
\text { victimisation } \\
\text { - Narratives of territorial } \\
\text { insecurity and perceived } \\
\text { risk of electoral loss/gain } \\
\text { - Potential frame } \\
\text { outcomes: Intergroup } \\
\text { attack and counter-attack } \\
\text { as a means to achieve } \\
\text { intended goals; rebellious } \\
\text { attitudes }\end{array}$ & $\begin{array}{l}\text { - Compromise } \\
\text { with respect to } \\
\text { the perceived } \\
\text { misrepresentation } \\
\text { of self/group } \\
\text { - Narratives of national } \\
\text { insecurity and the urgency } \\
\text { to reconcile electoral loss/ } \\
\text { gain perceptions } \\
\text { - Potential frame outcomes: } \\
\text { Intergroup attack and } \\
\text { counter-attack as a means } \\
\text { to achieve intended goals; } \\
\text { rebellious attitudes }\end{array}$ \\
\hline
\end{tabular}

\section{Figure 1: Shifts in vernacular radio frames and changes in intergroup attitudes during violence}

Although Figure 1 appears to suggest linearity in its frame sequence, it should be noted that post-conflict discourse can fall back to pre-conflict or active violence frames depending on how the perceived differences are negotiated across groups, time, and space. That is, depending on frame categories, violence is more likely to escalate or de-escalate as people's perception of electoral stakes shifts. This includes the outcome of violence such as the number of victims, damage to property and increased insecurity. Even in the de-escalation process, if the narratives of compromise and reconciliation no longer reflect the perceived 
collective interests, the framing may relapse into that of pre-conflict ${ }^{1}$. As a result, another violent incident might take shape because of these latent forces, and possibly transform into lasting conflict. The dilemma in the de-escalation process may be twofold. First, radio hosts may be driven by the conviction that encouraging diversity of views (e.g. through phone-in programmes and music on air) strengthens democratic participation in matters relating to election violence. This rests on the assumption that the inclusive voice is key to conflict resolution. On the other hand, encouraging diverse positions on air requires a delicate balance between positions and intended outcomes, especially when certain voices advocate justified violence against the perceived outsiders. While the former poses the question of credibility, integrity and autonomy with regard to vernacular radio frames, the latter is concerned with issues of sensationalism, objectivity and ethnic tolerance.

The findings also show that the narratives of cross-victimisation are more prevalent during times of conflict. This suggests that intergroup violence is likely to escalate whenever vernacular radio frames encourage their listeners to adopt defensive strategies such as attacks and counter-attacks instead of reconciliatory practices. Violence in this regard can also be used as a measure of power and/or weakness, thereby redefining intergroup relational boundaries. In the words of Jean-Jacques Rousseau (2008, p. 16):

the strongest is never strong enough to be always the master, unless he transforms strength into right, and obedience into duty. Hence the right of the strongest, which, though to all seeming meant ironically, is really laid down as a fundamental principle.

If it is true that violence can be framed as a means by which people test their power and redefine their relational boundaries, radio frames are therefore key in determining whether ongoing violence transforms into peaceful negotiations for long-term stability or escalates into more violence and a potential civil war.

In the aftermath of conflict, vernacular radio frames adopt narratives that cut across perceived group or party loyalties. Unlike the phases before and during active violence, post-conflict frames tend to repair broken relational bonds by strengthening collaborative attitudes. Radio listeners (understood here as potential participants in violence) may resort to short- or long-term solutions through compromise or by adopting what Covey (2011) calls the principle of

1 Violence in this regard can take other forms such as strong or unpleasant emotions/feelings directed toward another group. This may transcend the conventional understanding of violence as a physical harm. 
synergy ${ }^{2}$ to transcend acts of violence in the long term. For instance, perceived national interests, often defined along the lines of citizenship or national selfdetermination, were specifically emphasised following the active conflict phase. Narratives underpinning individual political interests were minimal.

Although post active violence narratives may not necessarily resolve deepseated feelings about the causes and consequences of electoral violence, they may alter the direction and intensity of violence. In this way, violence may either regain its latent nature (understood here as strong or unpleasant emotions/feelings directed toward another group) or encourage long-term solutions where both parties feel satisfied with the decisions reached. In other words, the elasticity of vernacular radio frames varies depending on the stage at which the violence manifests itself. Therefore, the shifts from electoral discourse to ethnicity are likely to be the result of the framing process and the degree of resonance of the proposed frames with regard to perceived fears, insecurities, and intended outcomes.

Ultimately, elasticity in the framing process can be understood in terms of fragmented and concerted framing. Differentiated framing may underscore a form of media/radio narrative whereby group differences are negotiated in terms of competition likely to generate intergroup polarisation. That is, one group or a coalition of groups is perceived as the primary beneficiary of an election outcome. This kind of framing is more likely to be prevalent before active violence and in its early stages, when claims of ethnic essentialism become the defining characteristics of nationhood or intergroup relations. Ethnicity, in this regard, is defined in terms of blood (consanguineal) kinship and common ancestry. Differentiated framing may reinforce feelings of exclusivity and/or competitive attitudes, giving less room for constructive dialogue or compromise between the perceived warring groups. Although differentiated framing may characterise intergroup tensions and subsequent intergroup violence, intra-group tensions may also stem from this kind of framing, especially when members of the same group are faced with intense competition from within.

In contrast, concerted framing describes radio and media narratives negotiated in terms of values that cut across intergroup interests, thereby reinforcing a sense of collective goals such as intergroup peace. Here, vernacular radio stations may choose to embrace narratives that call for intergroup reconciliation and cohesion, public safety, political integrity, and the rule of law. While there is no certainty that such frames will change the course of violence, they tend to instil collaborative

2 Covey defines the principle of synergy as 'what happens when one plus one equals ten or a hundred or even a thousand [because] it's the mighty result when two or more respectful human beings determine together to go beyond their preconceived ideas to meet a great challenge. It's all about the passion, the energy, the ingenuity, the excitement of creating a new reality that is far much better than the old reality' (p. 12). 
attitudes among groups and encourage the search for a common solution to acts of violence. Concerted framing is more likely to emerge in the late stages and aftermath of a prolonged phase of active violence. Here, vernacular radio narratives could potentially shift from emphasising intergroup competition to underpinning values and practices shared by the majority of the groups, such as the subtle emotional appeal of religious songs. Such practices may temporarily halt the violence while groups negotiate various options for peace. Ethnicity, in this regard, is not articulated as a sine qua non of blood kinship or common descent but instead are associated citizenship and national self-determination. Overall, concerted framing is likely to reinforce inclusive and collaborative attitudes that address intergroup differences through dialogue, compromise and synergy.

\section{CONCLUSION}

This article examined how vernacular radio narratives influence patterns of election violence, using the 2007-08 election crisis in Kenya as a case study and framing as an analytical framework. It goes beyond normative approaches that underpin ethno-political categorisation as the primary cause of electoral violence in multi-ethnic societies to examine the role of radio frames from the perspective of radio listeners in Kisumu, Eldoret and Nyeri. It showed that ethnic groups may profoundly differ in the ways they perceive each other and how they make sense of election violence based on the narratives circulated and their interpretations. The symbolic power of language and cultural allegiances is found to be a key driver of vernacular radio frames, as they infiltrate the inner feelings of various ethnolinguistic groups when giving meaning to different occurrences. Most importantly, vernacular radio frames can either be differentiated or concerted, depending on the levels at which the violence manifests itself, prompting divergent attitudes towards intergroup relations. Overall, the findings of this study offer insights into understanding how, why and when vernacular radio may be used to influence perceived electoral stakes and related violence.

\section{Acknowledgement}

An earlier version of this paper was presented at the 2012 Annual International Conference on Journalism \& Mass Communication and at the Annual Congress of the ACFAS (Association francophone pour le savoir) in 2013. 


\section{----- REFERENCES}

Altheide, DL 2009, 'Media and Mediated Evidence', Cultural Studies-Critical Methodologies, vol. 9 no. 1, pp. 14-22.

Avraham, E \& First, A 2010, 'Combining the representation approach with the framing concept: Television news coverage of the Arab population in Israel during conflict', Journalism, vol. 11, no. 4, pp. 481-499.

Barker, D \& Knight, K 2000, 'Political Talk Radio and Public Opinion' European Journal of Women's Studies, vol. 64, no. 2, pp. 149-70.

Bronstein, C 2005, 'Representing the Third Wave: Mainstream Print Media Framing of a New Feminist Movement', Journalism \& Mass Communication Quarterly vol. 82, no. 4, pp. 783-803.

Brown, S 2011, 'Lessons Learned and Forgotten: The International Community and Electoral Conflict Management in Kenya', In D Gillies (ed.), Elections in Dangerous Places: Democracy and the Paradoxes of Peacebuilding, pp. 127-43, McGill-Queen's University Press, Montreal.

Chepkoech, A 2015, 'How the ICC charges turned my world upside down', Daily Nation 5 July. Available at https://www.nation.co.ke/lifestyle/lifestyle/joshua-sang-ICC-charges-turned-my-world-upside-down/12142775408-15gkxpf/index.html [accessed, 2019].

Cohen, AP 1994, Self-Consciousness: An alternative anthropology of identity, Routledge, London.

Cottrell, J \& Ghai, Y 2007, 'Constitution Making and Democratization in Kenya (2000-2005)', Democratization, vol. 14, no. 1, pp. 1-25.

Covey, S 2011, 'The Third Alternative: Solving World's Most Difficult Problems', Free Press, New York.

D'Angelo, P 2011, 'Studying Framing in Political Communication with an Integrative Approach', American Behavioral Scientist, vol. 56, no. 3, pp. 353364.

El-Nawawy, M \& Powers, S 2010, 'Al-Jazeera English: A conciliatory medium in a conflict-driven environment?', Global Media and Communication, vol. 6, 1, pp. 61-84.

Entman, RM 1993, 'Framing: Toward clarification of a fractured paradigm', Journal of Communication, vol. 43, 4, pp. 51-8.

Entman, RM 2010, 'Media framing biases and political power: Explaining slant in news of Campaign 2008', Journalism, vol. 11, 4, pp. 389-408.

Frère, M-S 2009, 'After the hate media: regulation in the DRC, Burundi and Rwanda', Global Media and Communication, vol. 5, 3, pp. 327-352.

Goffman, E 1974, 'Frame Analysis: An Essay on the Organization of Experience', Harvard University Press, Cambridge, MA. 
Gower, KK \& An, S-K 2009, 'How do the news media frame crises? A content analysis of crisis news coverage', Public Relations Review, vol. 35, pp. 107-112. Hammer, R \& Kellner, D (eds.) 2009. 'Media/Cultural studies: Critical approaches', Peter Lang Publishing Inc., New York.

Human Rights Watch 2009, 'Human Rights Watch world report', Human Rights Watch, New York.

Jamal, AI and Deane, M 2008, 'The 2007 general elections: the role of local language media', The International Journal of Press/Politics, vol. 13, no. 3, pp. 319-327.

Helander, E 2010, 'A critical view of the Kenyan media system through the perspective of the journalists', African Communication Research, vol. 3, no. 3, pp. 521-542.

Kaburahe, A 2004, 'La mémoire blessée', La Longue Vue, Brussels.

Kaufman, S \& Smith, J 1999, 'Framing and Reframing in Land Use Change Conflicts', Journal of Architectural and Planning Research, vol. 16, no. 2, pp. 164180.

Klaus, KD 2015, 'Claiming Land: Institutions, Narratives, and Political Violence in Kenya', PhD diss., University of Wisconsin-Madison.

Kolmer, C \& Semetko, HA 2009, 'Framing the Iraq War: Perspectives from American, U.K., Czech, German, South African, and Al-Jazeera News', American Behavioral Scientist, vol. 52, no. 5, pp. 643-656.

Lecheler, S \& de Vreese, CH 2012, 'News Framing and Public Opinion: A Mediation Analysis of Framing Effects on Political Attitudes', Journalism \& Mass Communication Quarterly, vol. 89, no. 2, pp. 185-204.

Lekgoathi, SP 2012, 'Ethnic Separatism or Cultural Preservation? Ndebele Radio under Apartheid, 1983-1994', South African Historical Journal, vol. 64, no. 1, pp. 59-80.

Lohner, J, Banjac, S, \& Neverla, I 2016, 'Mapping structural conditions of journalism in Kenya', Media Conflict and Democratization (Working Paper), University of Leeds.

Lynch, G 2008, 'Courting the Kalenjin: Failure of Dynasticism and the Strength of the ODM Wave in Kenya's Rift Valley Province', African Affairs, vol. 107, no. 429 , pp. 541-568.

Matthes, J 2012, 'Framing politics: An integrative approach', American Behavioral Scientist, vol. 56, no. 3, pp. 247-259.

Neyazi, TA 2010, 'Cultural imperialism or vernacular modernity? Hindi newspapers in a globalizing India', Media Culture Society, vol. 32, no. 6, pp. 907924.

Odhiambo, LO 2002, 'The Media Environment in Kenya Since 1990', African Studies, vol. 61, no. 2, pp. 295-318. 
Ogola, G 2011 'The political economy of the media in Kenya: from Kenyatta's Nation-building Press to Kibaki's local-Language FM radio', Africa Today vol. 57, 3, pp. 77-95.

Osaghae, EE 1999, 'Conflict Research in Africa', International Journal of World Peace, vol. 16, pp. 53-72.

Rasmussen, J 2010, 'Mungiki as youth movement: Revolution, gender and generational politics in Nairobi, Kenya', Young/Nordic Journal of Youth Research, vol. 18, no. 3, pp. 301-319.

Republic of Kenya 2008, Commission of Inquiry into Post-Election Violence (The Waki Report), Government Printer, Nairobi.

Rice, X 2008, 'We told them to come out of the church, but they locked the door ... So we burned them', The Guardian, accessed November 2010, https://www. theguardian.com/world/2008/jan/02/kenya1

Rousseau, J-J 2008, The social contract, tr GDH Cole, Cosimo Classics, New York. Royal Media Services 2019 https://www.royalmedia.co.ke [Accessed May 20, 2019]. Schweitzer, ME, DeChurch, LA \& Gibson, DE 2005, 'Conflict frames and the use of deception: are competitive negotiations less ethical?', Journal of applied psychology, vol. 35, no. 10, pp. 2123-214.

Shah, DV, McLeod, DM, Gotlieb, MR \& Lee, N 2009, 'Framing and agenda-setting'. In R Nabi \& MB Oliver (Eds.), Handbook of media processes and effects (pp. 8398), Sage, Los Angeles.

Simons, G 2008, 'Mass media and the battle for public opinion in the global war on terror: violence and legitimacy in Iraq', Perceptions, Spring-Summer 2008. Somerville, K 2009, ‘British media coverage of the post-election violence in Kenya, 2007-08', Journal of Eastern African Studies, vol. 3, no. 3, pp. 526-542.

Tewksbury, D \& Scheufele, DA 2009, 'News framing theory and research', In J Bryant \& MB Oliver (Eds.), Media effects: Advances in theory and research (3rd ed., pp. 17-33), Routledge, New York.

Thomson, A 2007, 'Media and the Rwanda genocide', Pluto Press, London.

Throup, DW \& Hornsby, C 1998, 'Multi-Party Politics in Kenya: The Kenyatta and Moi States and the Triumph of the System in the 1992 Elections', James Currey, Oxford.

Tomaselli, K \& Muller, J 2001, 'Narrating the Crisis: Hegemony and the South African Press', Critical Arts, vol. 6, no. 1, pp. 110-112,

Wanyande, P 1995, 'Mass Media-State Relations in Post-Colonial Kenya', African Media Review, vol. 9, no. 3, pp. 54-75.

Waweru, T 2018, 'Editors Guild condemns threats to media houses by Jubilee Government', Standard 30 January. Available at https://www.standardmedia.co.ke/article/2001267731/editors-guild-condemns-threats-to-mediahouses-by-jubilee-government [Accessed June 7, 2019]. 
Weaver, DH 2007, 'Thoughts on agenda setting, framing, and priming', Journal of Communication, vol. 57, no. 1, pp. 142-147.

Wolff, S 2004, 'Disputed territories: The transnational dynamics of ethnic conflict settlements', Berghan Books, New York.

Zuckerman, E 2009, 'Citizen media and the Kenyan electoral crisis', In S Allan \& E Thorsen (eds.), Citizen Journalism: Global Perspectives, Peter Lang, New York. 